\title{
Efektivitas Strategi Bauran Pemasaran Terhadap Daya Saing Produk Boneka
}

\author{
Tiris Sudrartono \\ Politeknik Piksi Ganesha \\ Tiris.sudrartono@gmail.com
}

\begin{abstract}
Abstrak
Penelitian ini bertujuan untuk mengetahui efektivitas Strategi Bauran Pemasaran terhadap Daya Saing Produk. Dalam penelitian diperoleh hasil bahwa Strategi Produk, Strategi Harga, Strategi Distribusi serta Strategi Promosi apabila diterapkan dilaksanakan dengan baik maka Daya Saing Produk akan mengalami peningkatan yang signifikan. Model produk yang dihasilkan pun harus sesuai dengan keinginan pasar, merk produk harus mudah dibaca dan dingat oleh konsumen, ukuran produk dibuat standar dengan mencantumkan pada Merk Produksi, Menyediakan bahan baku yang selalu tersedia dengan harga kompotitif dan kualiatas dan Memilih media yang tepat dalam promosi produk sehingga strategi yang digunakan bisa lenih efektiv dalam meningkatkan daya saing produk.
\end{abstract}

Kata kunci : Strategi Bauran Pemasaran, Daya Saing

\begin{abstract}
This study aims to determine the effectiveness of the Marketing Mix Strategy on Product Competitiveness. In this research, the results show that the Product Strategy, Price Strategy, Distribution Strategy and Promotion Strategy if implemented well, the Product Competitiveness will experience a significant increase. The resulting product model must be in accordance with market desires, the product brand must be easily read and remembered by consumers, the size of the product is made standard by including on the Production Brand, Providing raw materials that are always available at competitive prices and quality and Choosing the right media in product promotion so the strategy used can be more effective in increasing product competitiveness.
\end{abstract}

Keyword: Marketing Mix Strategy, Competitiveness

\section{PENDAHULUAN}

Peranan dan keberadaan sektor Usaha Kecil dan Menengah (UKM) di Indonesia diakui sangat penting dalam perekonomian nasional.Selama krisis ekonomi, UKM telah berperan dalam penyerapan tenaga kerja, pemberian pelayanan ekonomi yang luas kepada masyarakat dan dalam proses pemerataan dan peningkatan pendapatan masyarakat. Selain itu UKM juga berperan dalam perkembangan struktur produksi dan distribusi karena pada umumnya kegiatan produksi UKM memerlukan keterkaitan yang luas dengan kegiatan usaha industry lainnya. Sebagai salah satu sektor yang sangat penting dituntut dan diharapkan dapat lebih meningkatkan peran dan kontribusinya secara nasional maupun regional.
Sentra Industri Boneka Sukamulya Kota Bandung merupakan salah satu dari banykanya sentra sentra industri di Indonesia, Sentra Industri ini didominasi oleh para pelaku usaha kecil dan menengah yang menjalankan aktivitasnya dengan memproduksi berbagi jenis boneka mulai dari yang ukuran kecil hingga super besar dengan harga yang terjangkau, setiap boneka dibandrol dengan harga yang berbeda muali dari puluhan ribu rupiah sampai dengan ratusan ribu rupiah, setiap pabrik di Sukamulya rata rata memproduksi 250 sampai dengan 1.000 unit boneka per bulannya, berikut data produksi boneka di sentra industri Sukamulya Bandung : 
Tabel 1.

\begin{tabular}{|c|c|c|c|c|c|}
\hline \multirow{3}{*}{ Pemilik Usaha } & \multicolumn{3}{|c|}{ Volume Usaha Produksi Boneka dalam } & \multirow{2}{*}{\multicolumn{2}{|c|}{$\%$ Naik-Turun }} \\
\hline & & Unit & & & \\
\hline & 2016 & 2017 & 2018 & 2017 & 2018 \\
\hline H. Enen Hidayat, JL BBK Caringin 04/04 & $1,740,000$ & $1,655,000$ & $1,500,00$ & $(0.95)$ & $(0.91)$ \\
\hline Dedi, Sukamulya Indah 03/04 & $1,540,225$ & $1,607,000$ & $1,605,000$ & 1.04 & 1.00 \\
\hline Hermanto, Sukamulya Indah 03/04 & 745,000 & 751,000 & 801,000 & 1.01 & 1.07 \\
\hline Kardiman, Sukamulya Indah 03/04 & $1,022,000$ & $1,020,000$ & $1,018,000$ & $(1.00)$ & $(1.00)$ \\
\hline Sumarna, Sumakmulya Indah 26 03/04 & 995,070 & 980,050 & 979,020 & $(0.98)$ & $(1.00)$ \\
\hline H. Abdurahman, BBK Caringin 31 03/04 & $1,445,000$ & $1,450,000$ & $1,470,000$ & 1.00 & 1.01 \\
\hline H. Encep Dargawan, BBK Caringin 04/04 & $1,200,300$ & $1,300,500$ & $1,150,100$ & 1.08 & 0.88 \\
\hline Hermanto, BBK Caringi 05/04 & $1,974,000$ & $1,990,000$ & $1,994,000$ & 1.01 & 1.00 \\
\hline H. Dayat Hidayat. BBK Caringin 05/04 & 788,000 & 779,000 & 775,000 & $(0.99)$ & $(0.99)$ \\
\hline H. Yanto Rukmana, BBK Caringin 04/04 & $1,225,000$ & $1,200,000$ & $1,201,000$ & $(0.98)$ & 1.00 \\
\hline H. Atang Abdul, BBK Caringin 04/04 & 985,000 & 993,000 & 997,000 & 1.01 & 1.00 \\
\hline H. Dede Suhana, BBK Caringin No.11 & $1,145,000$ & $1,100,000$ & $1,090,000$ & $(0.96)$ & $(0.99)$ \\
\hline Yanto, Sukamulya Indah No.18 & 655,000 & 653,000 & 650,500 & $(1.00)$ & $(1.00)$ \\
\hline C,.Cepi, Pagarsih No. 36 & $1,035,000$ & $1,070,000$ & $1,077,000$ & 1.03 & 1.01 \\
\hline Irina, Sukamulya Ujung No. 68 & $1,031,000$ & $1,027,000$ & $1,023,000$ & $(1.00)$ & $(1.00)$ \\
\hline Pinkan, Neglasari 4 & 455,000 & 460,000 & 461,000 & 1.01 & 1.00 \\
\hline Evi, BBK caringin 04/04 & $1,100,900$ & $1,088,700$ & $1,072,300$ & $(0.99)$ & $(0.98)$ \\
\hline Dadang, Sukamulya Indah 04/04 & $1,333,000$ & $1,315,000$ & $1,312,700$ & $(0.99)$ & $(1.00)$ \\
\hline Deden, BBK Caringin 05/04 & 720,000 & 742,000 & 725,000 & 1.03 & $(0.98)$ \\
\hline Acep Cecep, Sukamulya 04/04 & $1,005,000$ & $1,117,000$ & $1,135,000$ & 1.11 & 1.02 \\
\hline
\end{tabular}

Perkembangan Volume Usaha Industri Boneka Sukamulya Bandung

Sumber : Data Yang Diolah 2019

Dalam Tabel 1 dapat dijelasakan bahwa di Sentra Industri Boneka sukamulya Bandung tingkat produksi yang dihasilkan tiap tahunnya oleh setiap pengrajin tidak selalu meningkat dan bahkan dalam dua tahun terkahir ada beberapa pengrajin yang selalu mengalami jumlah produksi benekanya, hal ini di duga karena belum efektifnya pelaksanaan Strategi bauran Pemasaran yang dugunakan sehingga daya saing produk beneka di pasar menjdai rendah

Dari latar belakang yang telah diuraikan tersebut, maka penulis tertarik untuk melakukan penelitian dengan judul "Efektivitas Strategi Bauran Pemasaran Terhadap Daya Saing Produk Boneka"

\section{TUNJAUAN PUSTAKA}

\section{Efektivitas}

Menurut Ravinato (2014:11) Efektivitas adalah seberapa baik pekerjaan yang dilakukan, sejauh mana orang menghasilkan keluaran sesuai dengan yang diharapkan, artinya apabila suatu pekerjaan dapat diselesaikan sesuai dengan perencanaan, baik dalam waktu, biaya maupun mutunya maka dapat dikatakan efektif.

\section{Bauran Pemasaran (Marketing Mix)}

Menurut Philip Kotler (2005:17) "Bauran pemasaran adalah seperangkat alat pemasaran yang digunakan perusahaan untuk terus menerus mencapai tujan pemasarannya dalam pasar sasaran". Bauran pemasaran harus terus menerus digunakan untuk mencapai tujuan pemasaran di pasar sasaran, pasar sasaran adalah dimana perusahaan memutuskan segmen mana yang memperlihatkan peluang paling besar. Bauran pemasaran (marketing mix) memiliki empat variabel yang dapat mempengaruhi saluran perdagangan dan konsumen akhir. Keempat variabel tersebut adalah sebagai berikut:

1. Produk (product)

Merupakan sekumpulan atribut yang nyata dan tidak nyata. Menurut Philip Kotler (2005:17) produk adalah : "penawaran yang berwujud dari perusahaan kepada pasar yang mencakup keragaman produk, kualitas produk, design, merek, kemasan, ukuran, pelayanan, garansi dan imbalan."

2. Harga (price)

Harga merupakan nilai yang ada pada suatu produk yang dibutuhkan untuk mendapatkan produk dan pelayanan yang menyertainya. Maka dengan adanya harga diharapkan dicapainya laba (profit) yang tentunya dapat 
dicapai dengan tingkatan harga tertentu yang sesuai dengan harapan yang ingin dicapai. Harga sering digunakan sebagai alat kompetitif, bahkan dapat dikatakan bahwa persaingan harga yang ketat kadang-kadang dapat menyebabkan perang harga (price war). Harga juga dapat membantu membentuk citra sebuah produk.

3. Tempat (Place)

Tempat merupakan suatu sarana perpindahan produk yang dihasilkan produsen kepada konsumen akhir, sehingga perpindahan produk yang diharapkan dapat menciptakan adanya kecepatan dan ketepatan waktu. Pada dasarnya tempat yang baik dalam pemasaran adalah tempat yang mudah dijangkau oleh konsumen dan perusahaanpun mudah dalam membawa produknya kepada konsumen, mudah dalam distribusi barang dan nyaman bagi konsumen dalam proses pembelian.

4. Promosi (promotion)

Promosi, adalah meliputi semua kegiatan yang dilakukan perusahaan untuk mengkomunikasikan dan mempromosikan produknya kepada pasar sasaran. Promosi merupakan salah satu cara untuk menyampaikan informasi suatu produk melalui kombinasi periklanan, personal selling, promosi penjualan dan pubisitasnya.

\section{Daya Saing}

Perusahaan yang tidak mempunyai daya saing akan ditinggalkan oleh pasar. Karena tidak memiliki daya saing berarti tidak memiliki keunggulan, dan tidak unggul berarti tidak ada alasan bagi suatu perusahaan untuk tetap survive di dalam pasar persaingan untuk jangka panjang. Daya saing berhubungan dengan bagaimana efektivitas suatu organisasi di pasar persaingan, dibandingkan dengan organisasi lainnya yang menawarkan produk atau jasa-jasa yang sama atau sejenis. Perusahaan-perusahaan yang mampu menghasilkan produk atau jasa yang berkualitas baik adalah perusahaan yang efektif dalam arti akan mampu bersaing.

Dimensi daya saing suatu perusahaan sebagaimana dikemukakan oleh Muhardi (2007:40) dengan mengutip Ward et all (1998:1036-1037) adalah terdiri dari biaya (cost), kualitas (quality), waktu penyampaian (delivery), dan fleksibilitas (flexibility). Keempat dimensi tersebut lebih lanjut diterangkan oleh Muhardi (2007:41) lengkap dengan indikatornya sebagai berikut :

Dimensi-deimensi penentu daya saing industry UKM sebagai berikut :
1. Faktor Produksi adalah input yang dipakai oleh suatu industry UKM untuk menghasilkan produk, Faktor tersebut meliputi sumber daya alam, tenaga kerja, pengetahuan dan teknologi, modal, dan peralatan industri.

2. Permintaan Domestik, Tiga atribut permintaan industry UKM yang mempunyai pengaruh signifikan terhadap daya saing yaitu komposisi permintaan, perilaku pembeli, dan pola pertumbuhan permintaan konsumen,

3. Dukungan industri terkait, Keberadaan industri pendukung atau yang berhubungan dengan baik yang berada di dalam negeri maupun yang ada di luar negeri. Industri tersebut misalnya penyedia bahan baku, industri jasa pemasaran .

4. Strategi Perusahaan, Strategi perusahaan adalah pola sasaran, tujuan dan kebijakan umum untuk meraih tujuan yang telah ditetapkan, yang dinyatakan dengan mendefinisikan target pemasaran,laba yang diharapakan dan manajemen pengelolaan perusahaan yang dijalankan perusahaan atau yang seharusnya dijalankan oleh perusahaan

\section{METODE PENELITIAN}

Metode yang digunakan dalam penelitian ini adalah metode deskriptif, yaitu metode yang mempelajari, memahami dan menganalisis secara intensif data yang berkaitan dengan masalah sehingga dengan data tersebut dapat menggambarkan dan memperjelas masalah yang diidentifikasikan. sifat dari penelitian deskriptif ini bertujuan untuk mendapatkan gambaran serta informasi yang lebih mendalam mengenai efektivitas penerapan Strategi bauran pemasaran dan daya saing serta melakukan identifikasi masalah yang dihadapi oleh para pelaku UKM di sentra industri boneka Sukamulya Bandung mengenai peningkatan daya saing produk boneka di kota Bandung.

\section{Kerangka Berpikir}

Efektivitas Strategi Bauran Pemasaran melalui unsure-unsurnya yaitu Product, Price, Place, Promotion secara langsung ataupun tidak langsung memberikan kostribusi besar terhadap peningkatan Daya saing produk boneka di Sentra Industri Boneka Sukamulya Bandung. Lebih jelasnya dapat ditunjukkan pada kerangka pikir di bawah ini : 


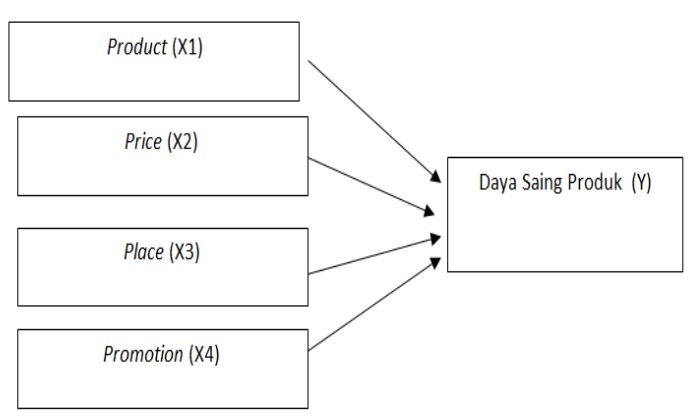

Gambar 1.Kerangka Berpikir

Sumber : Data yang dioleh dalam penelitian (2019)

\section{Populasi dan Sample Penelitian}

Tehnik yang digunakan dalam penelitian ini adalah tehnik sampling yaitu tehnik pengambilan sampel yang akan digunakan dalam penelitian dengan mengambil sebagian populasi. Populasi adalah wilayah generalisasi yang terdiri dari atas:obyek/subyek yang mempunyai kualitas dan karakteristik tertentu yang ditetapkan oleh peneliti untuk dipelajari dan kemudian ditarik kesimpulan.( Sugiyono, 2014:80). Dalam penelitian ini populasinya sebanyak 20 UKM. Sedangkan sample adalah bagian dari jumlah dan karakteristik yang dimiliki populasi tersebut artinya hanya sebagian dari populasi saja yang diambil dan digunakan untuk menentukan sifat serta ciri yang dikehendaki dari populasi.

Salah satu metode yang digunakan untuk menentukan jumlah sampel adalah menggunakan sample dari populasi tertentu yang dikembangkan oleh Issac dan Michel (Dalam Sugiono, 2014:86) semakin kecil toleransi maka semakin akurat sampel menggambarkan populasi. Jumlah pelaku usaha yang diteliti ada ada 20 tempat kegiatan usaha produk boneka dengan tingkat kesalahan pengambilan sample $10 \%$ maka jumlah sampel sebagai berikut :

$$
s=\frac{\lambda^{2} \text { N.P.Q }}{d^{2}(1-N)+\lambda^{2} \cdot P \cdot Q}
$$

Keterangan:

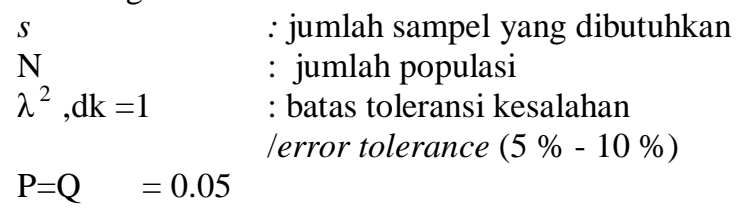

$$
s=\frac{0.1 \cdot 20.0 .05}{1(20-1) 0.1 .05}
$$

dengan demikian, jumlah sampel yang dibutuhkan peneliti adalah sebanyak 19 pelaku usaha.

\section{Pengumpulan Data}

1. Studi Lapangan (Field Research)

Teknik pengumpulan data dengan cara melakukan penelitian secara langsung terhadap obyek peneitian melalui beberapa cara yaitu:
a. Kuesioner merupakan teknik pengumpulan data yang dilakukan dengan cara memberi seperangkat pertanyaan atau pernyataan tertulis kepada responden untuk dijawabnya.
b. Wawancara yaitu teknik penelitian yang dilakukan dengan cara mengajukan sejumlah pertanyaan kepada pihak perusahaan yang bersangkutan, yang dimaksudkan untuk memperoleh inormasi yang dibutuhkan dalam penelitian.
c. Observasi yaitu teknik penelitian yang dilakukan dengan cara melakukan pengamatan dan peninjauan langsung pada obyek penelitian.

2. Studi Pustaka (Library Research)

Teknik pengumpulan data yang dilakukan dengan cara mempelajari buku-buku, literature dan dokumen-dokumen dengan maksud untuk memperoleh informasi yang bersifat teoritis mengenai hal-hal yang erat hubungannya dengan masalah yang diteliti mengenai masalah Segmentasi Pasar dan Penjualan.

\section{HASIL DAN PEMBAHASAN}

Sentra Industri Boneka Sukamulya terletak di jalanSukamulya, Kecamatan Sukajadi, Bandung, Fokus Sentra Industri Sukamulya adalah memproduksi berbagi jenis boneka seperti karekter tokoh kartun, binatang, enoticon, bantal dan lain lain. Terdapat kurang lebih 20 pelaku usaha kecil dan menengah ( UKM ) atau sering disebut pengarajin boneka. Kapasitas produksi per tahun nya bisa mencapai 768.940 unit dengan nilai investasi Rp. 2.691.000.000.- dan menyerap tenaga kerja sebanyak 212 orang, Namun kapasitas produksi tersebut memungkinkan untuk dapat ditingkatkan.

Berdasarkan kusioner yang disebar kepada para pengerajin dan pelaku usaha boneka sebanyak 19 orang, Dapat diketahui tanggapan dan pernyataan yang disampaikan seperti yang tercantum pada tabel 1 dan tabel. 2 berikut ini : 
Tabel 2.

Rekapitulasi Jawaban Responden Tentang Efektivitas Strategi Bauran Pemasaran

\begin{tabular}{|c|c|c|c|c|c|c|c|c|c|}
\hline No & Pernyataan & SS & $\mathbf{S}$ & KS & TS & STS & $\begin{array}{l}\text { Skor } \\
\text { Total }\end{array}$ & $\%$ & $\begin{array}{c}\text { Kriteria } \\
\text { Nilai }\end{array}$ \\
\hline \multicolumn{10}{|c|}{ PRODUK } \\
\hline 1 & $\begin{array}{l}\text { Keragaman Produk Boneka yang dihasilkan } \\
\text { telah sesuai dengan keinginan pasar }\end{array}$ & 4 & 7 & 7 & 1 & 0 & 71 & 74.7 & Baik \\
\hline 2 & $\begin{array}{l}\text { Kualitas Produk Boneka yang dihasilkan dinilai } \\
\text { baik }\end{array}$ & 4 & 8 & 6 & 1 & 0 & 72 & 75.8 & Baik \\
\hline 3 & $\begin{array}{l}\text { Disain produk Boneka selalu menyesuaikan } \\
\text { dengan keinginan pelanggan }\end{array}$ & 5 & 10 & 3 & 1 & 0 & 76 & 80 & Baik \\
\hline 4 & $\begin{array}{l}\text { Bentuk produksi Boneka yang dihasilkan sesuai } \\
\text { dengan keinginan berbagi kalangan usia dan } \\
\text { jenis kelamin }\end{array}$ & 1 & 6 & 9 & 3 & 0 & 62 & 65.2 & Cukup \\
\hline 5 & $\begin{array}{l}\text { Merk yang dipasang sulit dibaca dan diingat } \\
\text { oleh pelanggan }\end{array}$ & 1 & 11 & 7 & 0 & 0 & 44 & 46.3 & $\begin{array}{l}\text { Tidak } \\
\text { Baik }\end{array}$ \\
\hline 6 & Kemasan produl Boneka rapih, kuat dan menarik & 11 & 4 & 4 & 0 & 0 & 83 & 87.4 & $\begin{array}{c}\text { Sangat } \\
\text { Baik }\end{array}$ \\
\hline 7 & $\begin{array}{l}\text { Ukuran produk Boneka yang dihasilkan tidak } \\
\text { sesuai dengan ukuran standar nasional }\end{array}$ & 3 & 9 & 7 & 0 & 0 & 42 & 44.2 & $\begin{array}{l}\text { Tidak } \\
\text { Baik }\end{array}$ \\
\hline 8 & $\begin{array}{l}\text { Pelayanan kepada pelanggan dengan ramah dan } \\
\text { sopan santun dalam menjelaskan produk Boneka }\end{array}$ & 3 & 12 & 2 & 2 & 0 & 73 & 76.8 & Baik \\
\hline 9 & $\begin{array}{l}\text { Jaminan berupa kualitas mutu produk Boneka } \\
\text { disampaikan kepada pelanggan secara tertulis }\end{array}$ & 4 & 2 & 7 & 6 & 0 & 61 & 64.2 & Cukup \\
\hline 10 & $\begin{array}{l}\text { Pengembalian produk Boneka yang cacat } \\
\text { dilakukan dengan ganti rugi yang sepadan }\end{array}$ & 3 & 9 & 5 & 2 & 0 & 70 & 73.6 & Baik \\
\hline \multicolumn{7}{|c|}{$\begin{array}{l}\text { Persentase pencapaian Startegi Produk mencapai } 68.8 \% \text { dan skor nilai } 654 \\
\text { Kriteria nilai sebesar } 68.8 \% \text { adalah BAIK }\end{array}$} & 654 & $\sum_{68.8 \%}$ & Baik \\
\hline \multicolumn{10}{|c|}{ B. $\quad$ HARGA } \\
\hline 1 & $\begin{array}{l}\text { Daftar Harga disematkan dalam setiap produk } \\
\text { yang dihasilkan }\end{array}$ & 4 & 7 & 7 & 1 & 0 & 71 & 74.7 & Baik \\
\hline 2 & $\begin{array}{l}\text { Diskon diberikan kepada pelanggan dengan } \\
\text { kriteria tertentu }\end{array}$ & 4 & 5 & 8 & 2 & 0 & 68 & 71.5 & Baik \\
\hline 3 & $\begin{array}{l}\text { Potongan harga khusus diberikan untuk momen } \\
\text { momen tertentu seperti hari raya keagamaan }\end{array}$ & 5 & 10 & 3 & 1 & 0 & 76 & 80 & Baik \\
\hline 4 & $\begin{array}{l}\text { Periode pembayaran diberikan bagi pelanggan } \\
\text { yang melakukan pemebilian non tunai }\end{array}$ & 3 & 12 & 4 & 0 & 0 & 75 & 78.9 & Baik \\
\hline 5 & $\begin{array}{l}\text { Syarat kredit bagi pelanggan diberikan } \\
\text { kemudahan dan dengan kesepakatan bersama }\end{array}$ & 2 & 8 & 6 & 3 & 0 & 66 & 69.4 & Baik \\
\hline \multicolumn{7}{|c|}{$\begin{array}{l}\text { Persentase pencapaian Startegi Harga mencapai } 74.9 \% \text { dan skor nilai } 356 \\
\text { Kriteria nilai sebesar } 74.9 \text { adalah BAIK }\end{array}$} & 356 & $\begin{array}{c}\sum_{74.9} \\
\%\end{array}$ & Baik \\
\hline \multicolumn{10}{|c|}{ C. $\quad$ DISTRIBUSI } \\
\hline 1 & $\begin{array}{l}\text { Saluran pemasaran dilakukan melalui pasilitas } \\
\text { perusahaan kepada pelanggan } \\
\text { Ruang lingkup pemasaran wailayah }\end{array}$ & 3 & 6 & 6 & 4 & 0 & 65 & 68.4 & Baik \\
\hline 2 & $\begin{array}{l}\text { kabupaten/kota dan provinsi melalui survey } \\
\text { pasar }\end{array}$ & 2 & 6 & 7 & 4 & 0 & 63 & 66.3 & Cukup \\
\hline 3 & $\begin{array}{l}\text { Pengelompokan pelanggan dilakukan dalam } \\
\text { menyalurkan hasil produski }\end{array}$ & 5 & 10 & 3 & 1 & 0 & 76 & 80 & Baik \\
\hline 4 & $\begin{array}{l}\text { Lokasi pemasaran telah ditentukan dalam rangka } \\
\text { menjaring pasar potensial }\end{array}$ & 3 & 9 & 7 & 0 & 0 & 72 & 75.7 & Baik \\
\hline 5 & $\begin{array}{l}\text { Persediaan produksi Boneka dilakukan untuk } \\
\text { mengantisipasi pembelian berlebih dari } \\
\text { pelanggan }\end{array}$ & 2 & 8 & 6 & 3 & 0 & 66 & 69.4 & Baik \\
\hline 6 & $\begin{array}{l}\text { Transportasi dipilih dan ditetapkan yang paling } \\
\text { efesien dengan pertimbngan biaya produksi }\end{array}$ & 7 & 8 & 4 & 0 & 0 & 79 & 83.1 & Baik \\
\hline \multicolumn{7}{|c|}{$\begin{array}{l}\text { Persentase pencapaian Startegi Distribusi mencapai } 73.8 \% \text { dan skor nilai } 421 \\
\text { Kriteria nilai sebesar } 73.8 \text { adalah BAIK }\end{array}$} & 421 & $\sum_{73.8}$ & Baik \\
\hline \multicolumn{10}{|c|}{$\begin{array}{ll}\text { D. } & \text { PROMOSI }\end{array}$} \\
\hline 1 & $\begin{array}{l}\text { Promosi penjualan dilakukan melalui mulut ke } \\
\text { mulut dan media on line }\end{array}$ & 4 & 5 & 9 & 1 & 0 & 69 & 72.6 & Baik \\
\hline 2 & $\begin{array}{l}\text { Periklanan dilakukan pada tempat tempat } \\
\text { startegis }\end{array}$ & 4 & 7 & 7 & 1 & 0 & 71 & 74.7 & Baik \\
\hline 3 & $\begin{array}{l}\text { Usaha penjualan dilakukan melalui bazaar, } \\
\text { pameran, seminar-seminar dan pecan } \\
\text { kebudayaan daerah }\end{array}$ & 5 & 10 & 3 & 1 & 0 & 76 & 80 & Baik \\
\hline 4 & $\begin{array}{l}\text { Hubungan masyarakat dibina melalu CSR } \\
\text { sebagai bagian dari promosi }\end{array}$ & 5 & 8 & 6 & 0 & 0 & 75 & 78.9 & Baik \\
\hline 5 & $\begin{array}{l}\text { Pemasaran langsung oleh bagian pemasaran } \\
\text { melalui outlet/toko yang dimilki perusahaan }\end{array}$ & 2 & 7 & 10 & 0 & 0 & 68 & 71.5 & Baik \\
\hline \multicolumn{6}{|c|}{$\begin{array}{l}\text { Persentase pencapaian Startegi Promosi mencapai } 75.5 \% \text { dan skor nilai } 359 \\
\text { kriteria nilai sebesar } 75.5 \text { adalah BAIK }\end{array}$} & & 359 & $\sum_{75.5}$ & Baik \\
\hline \multicolumn{7}{|c|}{ Total skor Strategi Bauran Pemasaran } & 1790 & & \\
\hline \multicolumn{7}{|c|}{ \% berdasarkan Skor Harapan Strategi Bauran Pemasaran } & & 72.5 & BAIK \\
\hline
\end{tabular}


Pada tabel 2. rekapitulasi jabawan responden tentang efektivitas Stratgei Bauran pemasaran, sebanyak 19 Responden menyatakan baik dan telah dianggap efektif dalam melakukan strategi bauran pemasaran dalam kegiatan usahanya dengan pencapaian tanggapan sebesar $72.5 \%$ kriteria nilai Baik

Tabel 3.

Rekapitulasi Jawaban Responden Tentang Daya Saing Produk Boneka Sukamulya

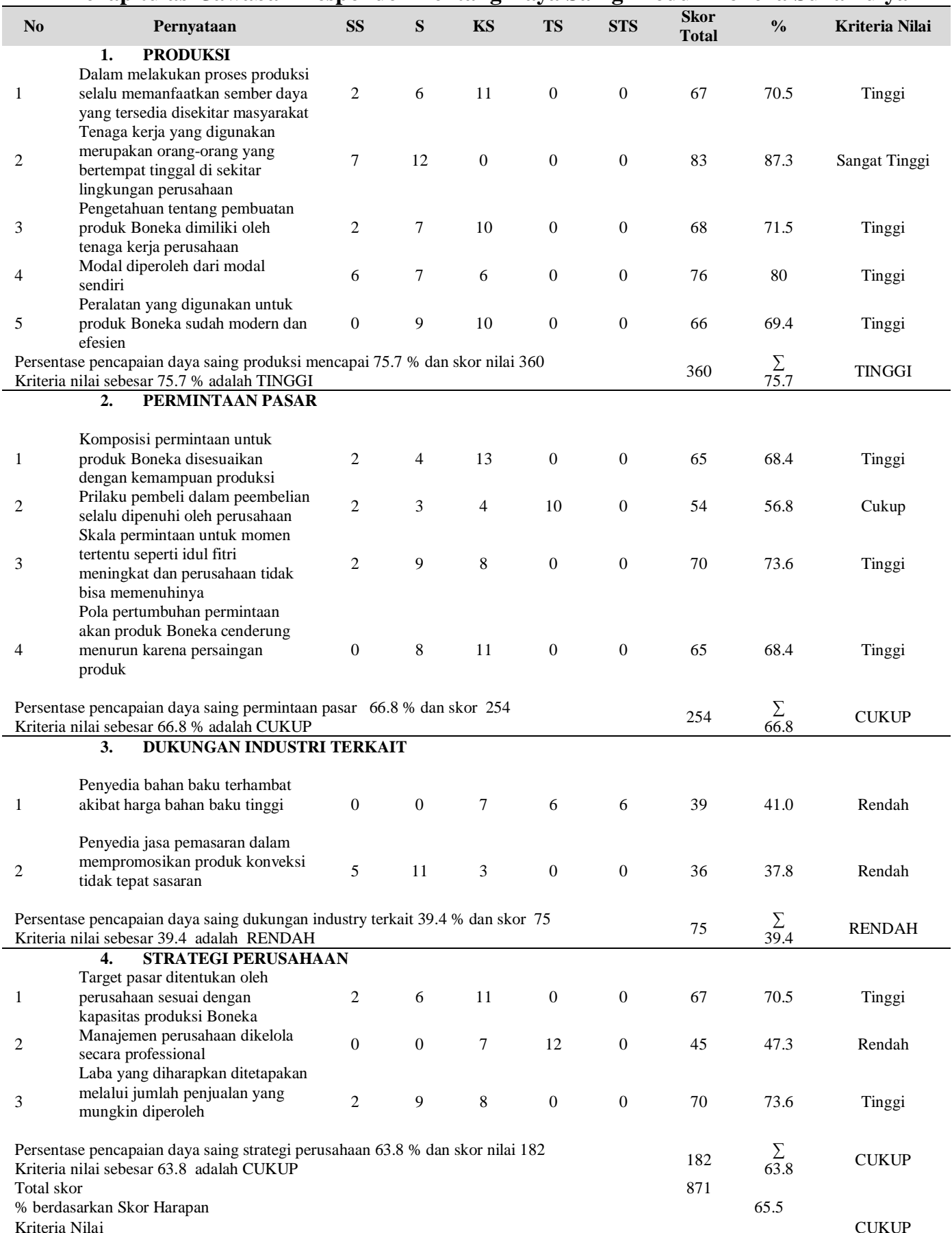

Sumber : Data Primer yang diolah, 2019 
Pada tabel 3. rekapitulasi jawaban responden tentang daya saing produk boneka sebnyak 19 responden menyatakan bahwa daya saing produk yang dihasilkan oleh para pengrajin di sentra industri boneka adalah cukup dengan besaran nilai $65.5 \%$

\section{Efektivitas Strategi Bauran Pemasaran Terhadap Daya Saing Produk}

Untuk mengetahui seberapa kuat pengaruh antara Variabel bebas Produk, Harga, Distribusi dan Promosi terhadap variabel terikat Daya Saing Produk boneka di Sentra Industri Boneka Sukamulya Bandung maka digunakan pengolahan data penelitian dengan mempergunakan program SPSS Versi 20, dan diperoleh hasil sebagai berikut:

Tabel 4

Pengolahan data Efektivitas Strategi Bauran Pemasaran terhadap Daya Saing Produk Boneka

\begin{tabular}{clllll}
\hline \multirow{2}{*}{ Model } & & $\begin{array}{l}\text { Sumof } \\
\text { Squares }\end{array}$ & df & $\begin{array}{l}\text { Mean } \\
\text { Square }\end{array}$ & F \\
\hline 1 & Regression & 64,278 & 4 & 16,070 & \\
& Residual & 36,340 & 14 & 2,596 \\
& Total & 100,618 & & & \\
& & & & & \\
\end{tabular}

a. Predictors (Constant), X4, X1, X3, X2

b. Dependent Variable: Y

Sumber : Pengelohan Data SPSS V.20

Berdasarkan pengolahan penelitian pada tabel 4. maka untuk menggambarkan Efektivitas Strategi Bauran pemasaran terhadap Daya Saing Produk Boneka maka dapat dijelaskan sebagai berikut :

A. Variabel X1 ( Produk ) $----------\rightarrow 0.518----\rightarrow$ Daya Saing Produk Boneka

B. Variabel X2 ( Harga ) $----------\rightarrow 1.019 \rightarrow---\rightarrow$ Daya Saing Produk Boneka

C. Variabel X3 ( Distribusi ) $--------\rightarrow 0.616 \rightarrow--\rightarrow$ Daya Saing Produk Boneka

D. Variabel X4 ( Promosi ) $-------\rightarrow 1.133 \rightarrow$ Daya Saing Produk Boneka

1. Jika Strategi Produk yang diterapkan dilaksanakan dengan baik maka Daya Saing Produk boneka akan mengalami peningkatan sebesar 0,518 satu satuan. Dan sebaliknya jika Strategi Produk tidak dilaksanakan dengan baik maka Daya Saing Produk Boneka akan mengalami penurunan sebesar 0,518 satu satuan dengan asumsi ceteris paribus. Pada penelitian ini dapat disampaikan salah satu variabel yaitu yaitu strategi produk bentuk kemasan produk boenaka rapih, kuat dan menarik diterapkan dengan baik sehingga daya saing dapat meningkat sebesar 0.518 satu satuan sedangkan untuk variabel bentuk produksi yang dihasilkan tidak sesuai dengan keinginan berbagai kalangan usia dan jenis kelamin sehingga daya saing turun sesesar 0,518 satu satuan. Hal ini penting dilakukan karena produk yang menjangkau semua kalangan masyarakat akan lebih disukai dan konsumen lebih banyak pilihan akan produk yang meraka inginkan sehingga daya saing produk akan tetap tinggi.

2. Jika Strategi Harga yang diterapkan dilaksanakan dengan baik maka Daya Saing Produk Boneka akan mengalami peningkatan sebesar 1,019 satu satuan. Dan sebaliknya jika Strategi harga tidak dilaksanakan dengan baik maka Daya Saing Produk Boneka akan mengalami penurunan sebesar 1,019 satu satuan dengan asumsi ceteris paribus. Dalam penelitian ini dapat disampaikan salah satu varibel yaiti jika Startegi harga berupa daftar harga disematkan pada hasil produksi Boneka maka daya saing produk boneka akan naik sebesar 1,019 satu satuan begutu juga apabila daftar harga tidak disematkan pada hasil produk yang dihasilkan maka daya saing produk tersebut akan turun sebesar 1.019 satu satuan karna disebabkan daftar harga yang tidak ada.daftar harga penting disematkan pada produk yang dihasilkan karena konsumen dapat langsung mengetahui daya beli atas produk boneka tersebut dan hal ini dapat meningkatkan daya tarik konsumen terhadap produk yang dihasilakn sehingga mempengaruhi daya saing produk boneka tersebut.

3. Jika Strategi Distribusi yang diterapkan dilaksanakan dengan baik maka Daya Saing Produk Boneka akan mengalami peningkatan sebesar 0,616 satu satuan. Dan sebaliknya jika Strategi Distribusi tidak dilaksanakan dengan baik maka Daya Saing Produk boneka akan mengalami penurunan sebesar 0,616 satu satuan dengan asumsi ceteris paribus. Pada penelitian didapat bahwa variabel survey pasar tidak dilakukan oleh para pengusaha di sentra industry boneka sehingga daya saing produk menjadi turun sebesar 0.616 satu satuan, lain hal nya apabila survey pasar dilakukan oleh para pengusaha di sentra industry boneka Sukamulya Banudng maka daya saing akan meningkat sebesar 0.616 satu satuan, survey pasar ini penting dilakukan untuk mengetahui sejauh mana produk yang dihasilkan dapat memenuhu keinginan konsumen sehingga produk yang dihasilkan beteul-betul diharapakan oleh para konsumen.

4. Jika Strategi Promosi yang diterapkan dilaksanakan dengan baik maka Daya Saing Produk boneka akan mengalami peningkatan sebesar 1,133 satu satuan. Dan sebaliknya jika Strategi Promosi tidak dilaksanakan dengan 
baik maka Daya Saing Produk boneka akan mengalami penurunan sebesar 1,133 satu satuan denganasumsi ceteris paribus. Salah satu variabel dalam penelitian ini adalah promosi dilakukan di temapt-tempat startgi dilaksanakan dengan baik maka daya saing akan meningkat sebesar 1.133 satu satuan, ini penting dilakukan karena promsosi yang tepat sasaran akan banyak menjaring para calon konsumen sehingga produk-produk yang dihasilkan oleh sentra industry Boneka Sukamulya Bandung banyka dikenal oleh banyak kalangan masyarakat sehingga daya saing produk Boneka ini tetap tinggi, promosi tidah harus melalui biaya tinggi salah satu nya adalah dengan tetap menjaga kualitas barang yang tetap kosisten bagus, sehingga secara tidak langsung pelanggan akan menyampaikan kepuasannya kepada orang lain dan ini menjadi bagian promosi yang lebih efektif dan efesian bagi para pengusaha.

Untuk mengetahui sejauh mana hubungan, perubahan dan pengaruh secara bersama sama Strategi Bauran pemasaran terhadap Daya Saing Produk Boneka di Sentra Industri Boneka Sukamulya Bandung, maka hasil penelitian diperoleh penjealsan sebagai beikut :

\section{Koefisien Korelasi ( $\mathbf{r}$ )}

Koefisien korelasi (r) menunjukkan hubungan keeratan antar variabel bebas dan variabel terikat. Semakin besar nilai koefisien korelasi semakin erat hubunganv ariabel bebas dan variabel terikat.

Pada hasil perhitungan dapat ditunjukkan bahwa besarnya nilai koefisien korelasi untuk persamaan yang dibahas yaitu sebesar $79,9 \%$. Ini berarti adanya hubungan yang cukup erat antara variabel bebas dengan variabel terikat karena mendekati nol. Dalam penelitian ini dapat disampaikan bahwa Strategi bauran pemasaran memeliki hubungan yang erat terhadap tingkat daya saing produk boneka, nilai tingkat keeratan hubungan tesebut sebesar $79.9 \%$ artinya bahwa Startegi bauran pemasaran nyatanya ada hubungnnya dengan tingkat daya saing produk boneka di sentra industry konveksi boneka suka mulya Bandung.

\section{Koefisien Determinasi $\left(\mathbf{R}^{2}\right)$}

Dari hasil perhitungan bahwa koefisien determinasi $\left(\mathrm{R}^{2}\right)$ sebesar 0,639 . Ini berarti variasi perubahan variabel terikat sebesar $63,9 \%$ dipengaruhi oleh variasi perubahan variabel bebas dan sisanya sebesar $36,1 \%$ dipengaruhi oleh faktor lain di luar model. Dalam penelitian ini dapat disampaikan bahwa Daya Saing produk konveksi pada sentra industry boneka sukamulya Bandung akan dipengaruhi oleh strategi bauran pemasaran yang diterapkan oleh para pengusaha sebesar 63.9 $\%$ pada produksi yang dihasilkan, permintaan pasar, dukungan industrI terkait dan strategi dari perusahaan itu sendiri sedangkan sisanya sebesar 36.1 dipenagruhi oleh faktor-faktor lain seperti Iklim, demografi, sosial budaya masyarakat sekitar dan lain sebaginya yang diluar model penelitian ini.

\section{KESIMPULAN DAN SARAN}

\section{Kesimpulan}

Berdasarkan hasil analisis data yang telah dilakukan terhadap seluruh data yang diperoleh, maka dapat ditarik simpulan sebagai berikut :

1. Strategi bauran pemasaran yang terdiri dari variabel Produk, Harga, Distribusi dan Promosi dinyatakan oleh responden Baik dalam pelaksanaannya dengan skor nilai 1.790 atau persentase pencapaian sebesar $72.5 \%$ walaupun terdapat beberapa indikator yang dinilai Cukup yaitu Bentuk produksi Boneka yang dihasilkan sesuai dengan keinginan berbagi kalangan usia dan jenis kelamin serta dinilai tidak baik untuk indikator Merk yang dipasang sulit dibaca dan diingat oleh pelanggan dan Ukuran produk boneka yang dihasilkan tidak sesuai dengan ukuran standar

2. Daya Saing produk boneka yang terdiri dari variabel produksi, permintaan pasar. Dukungan industri terkait dan strategi perusahaan dinyatakan oleh responden memiliki daya saing cukup di pasar dengan skor nilai 871 atau persentase pencapaian sebesar $65.5 \%$ dan terdapat beberapa indikator daya saing yang dinilai Rendah yaitu Penyedia bahan baku terhambat akibat harga bahan baku tinggi, Penyedia jasa pemasaran dalam mempromosikan produk boneka tidak tepat sasaran dan Manajemen perusahaan dikelola secara profesional

3. Upaya-upaya yang dilakukan para pelaku di sentra industry boneka sukamulya Bandung dalam meningkatkan Daya Saing Produk yaitu dengan meningkatan Efektivitas strategi bauran pemasaran melalui penyediaan bahan baku yang selalu tersedia, promosi produk yang tepat sasaran dan mengelola perusahaan dengan manajemen yang tepat serta bekerja secara profesional

\section{Saran}

Untuk meningkatkan daya saing produk yang dihasilkan oleh sentra industri Boneka Sukamulya Bandung sehingga dapat bertahan di 
pasaran dan terus berkembang maka beberapa hal yang dapat dilakukan para Pengerajin dan pelaku usaha di sentra industri boneka Sukamulya Bandung yaitu sebagai berikut :

1. Menyesuaikan model produk yang dihasilkan dengan keinginan pasar dan model yang terbarukan atau model yang sedang digemari saat ini sesuai dengan usia dan jenis kelamin konsumen

2. Merk produk harus mudah dibaca dan dingat oleh konsumen melalui pengolahan earna dan gambar yang tepat dan menarik

3. Ukuran produk dibuat standar dengan mencantumkan pada Merk Produksi

4. Menyediakan bahan baku yang selalu tersedia dengan harga kompotitif dan kualiatas yang sesuai dengan spesifikasi produksi yang diharapkan

5. Memilih media yang tepat dalam promosi produk boneka misal melalui media masa yang sering dibaca oleh masyarakat misal koran daerah Jawa Barat dan Bandung TV .

\section{DAFTAR PUSTAKA}

Kotler, Philip. dan Keller, Kevin Lane, 2009. Manajemen Pemasaran, Jilid 1

Edisi Keduabelas, Alih Bahasa oleh Benyamin Molan, Jakarta: PT.

Indeks.

Muhardi (2007) Daya saing produk UKM, Yogyakarta. Andi Offset

Ravinanto (2014, Efektuvitas Organisasi, Erlangga. Bandung

Sugiyono. 2010. Metode Penelitian Kuantitatif Kualitatif dan $R \& D$. Bandung:

Alfabeta.

Tjiptono, Fandy. 1997. Strategi Pemasaran. Yogyakarta: penerbit Andi. 